\title{
PENGOLAHAN SAMPAH KOTA TERSELEKSI MENJADI REFUSED DERIVED FUEL SEBAGAI BAHAN BAKAR PADAT ALTERNATIF
}

\author{
DWI ARIES HIMAWANTO, ${ }^{1}$ R. DHIMAS DHEWANGGA ${ }^{,},{ }^{3}$ INDARTO,${ }^{2}$ HARWIN SAPTOADI, ${ }^{2}$ DAN TRI AGUNG \\ ROHMAT $^{2}$ \\ 1 Jurusan Teknik Mesin Fakultas Teknik, Universitas Sebelas Maret \\ 2,3 Jurusan Teknik Mesin dan Industri, Universitas Gadjah Mada \\ E-mail: dwi_ah@uns.ac.id
}

\begin{abstract}
ABSTRAK
Limbah Padat Kota (LMK) memiliki potensi besar sebagai bahan baku terbarukan untuk menghasilkan energi modern melalui termokimia yang disebut pyrolyis, dan proses densifikasi untuk membentuk. Refused Derived Fuels (RDF), yaitu LMK briket char. Pada artikel ini, analisis termogravimetri dilakukan untuk menganalisis karakteristik pembakaran briket dari briket LMK dan briket LMK char. Sampel dalam penelitian ini adalah $70 \%$ berat komponen organik LMK-30\% berat LMK komponen non organik. Sampel 20 gram ditempatkan dalam tungku yang temperaturnya meningkat $10^{\circ} \mathrm{C} / \mathrm{min}$ dan sampai suhu sampel mencapai $400^{\circ} \mathrm{C}$ dan ditahan selama 30 menit sebelum sampel didinginkan hingga mencapai suhu kamar. $100 \mathrm{ml} /$ menit nitrogen diperlihatkan dari bagian bawah tungku sebagai gas yang terbuang. Char yang sudah terbentuk dipadatkan dan kemudian ditandai dalam keseimbangan makro produksi, diadopsi dari Swithenbank et al. Sampel 3 gram ditempatkan dalam tungku yang temperaturnya meningkat dengan laju pemanasan yang dipilih sampai massa sampel hampir konstan. Penelitian menunjukkan bahwa efek pirolisis memberikan peningkatan nilai sampel pemanasan dan memberikan suhu pengapian lebih rendah dari char briket pembakaran.
\end{abstract}

Kata kunci: limbah padat kota, pirolisis, char, briket, $R D F$

\begin{abstract}
Municipal Solid Wastes (MSW) has great potential as a clean, renewable feedstock for producing modern energy carriers through thermochemical, called pyrolyis, and densification processes to form a Refused Derived Fuels (RDF), i.e MSW char briquette. In this article, thermogravimetry analysis has done to analyzed combustion characteristic of MSW briquette dan MSW char briquette. The sample in this research is 70\% wt MSW organic component -30\% wt MSW non organic component. The 20 gram sample is placed in the furnace whose temperature is increased $10^{\circ} \mathrm{C} / \mathrm{min}$ and until sample temperature reaches $400^{\circ} \mathrm{C}$ and held for 30 minutes before the sample is cooled into room temperature. $100 \mathrm{ml} / \mathrm{min}$ nitrogen is introduced from the bottom of furnace as a swept gas.. The formed char is densified and then characterized in a self manufactured macro balance, adopted from Swithenbank et al. The 3 gram sample is placed in the furnace whose temperature is increased wih the selected heating rate until sample mass nearly constant. The results of the research showed that the effect of pyrolysis give the increase of sample heating value and give the lower ignition temperature of char briquette combustion.
\end{abstract}

Key words: municipal solid wastes, pyrolysis, char, briquette, $R D F$

\section{PENDAHULUAN}

Sampah merupakan bahan yang terbuang dari hasil aktivitas manusia maupun proses alam yang tidak memiliki nilai ekonomi lagi, bahkan dapat menimbulkan dampak yang negatif. Selama ini sampah kota menjadi salah satu masalah lingkungan yang memerlukan penanganan yang sangat serius. Masalah yang sering muncul dalam penanganan sampah kota yang terus bertambah jumlahnya adalah biaya operasional yang tinggi dan semakin sulitnya ruang yang pantas untuk pembuangan, sehingga dalam penanganan sampah kota sering menimbulkan dampak yang buruk terhadap lingkungan. Pada umumnya, sampah dapat dibagi menjadi dua golongan yaitu sampah organik dan anorganik. Selama ini penanganan sampah kota di negara-negara berkembang seperti Indonesia hanya menimbun dan membakar langsung sampah di udara terbuka pada TPA (tempat pembuangan akhir). Hal ini juga tidak bisa mengurangi $100 \%$ sampah dan akan menimbulkan permasalahan yaitu produksi yang dihasilkan zat-zat polutan yang dapat mencemari lingkungan yaitu gas-gas hasil pembakaran seperti $\mathrm{CO}_{2}, \mathrm{NO}_{\mathrm{x}}, \mathrm{SO}_{2}$, dan lain-lain. 
Estimasi jumlah timbunan sampah di Indonesia pada tahun 2008 diperkirakan mencapai 38,5 juta ton/tahun dengan komposisi terbesar adalah sampah organik (58\%), sampah plastik (14\%), sampah kertas (9\%) dan sampah kayu (4\%). (Kementerian Negara Lingkungan Hidup, 2008). Teknologi untuk menangani sampah sebenarnya telah banyak dikembangkan terutama oleh negara-negara maju yaitu di antaranya teknologi sanitary landfill, incineration, gasification, dan anaerobic digestion. Salah satu cara pengolahan sampah yang dipandang cukup prospektif dilakukan adalah mengolah sampah kota menjadi $R D F$ (Refused Derived Fuel), yaitu mengolah sampah kota menjadi char/arang melalui proses pirolisis dan kemudian memadatkannya sehingga menjadi briket char.

Pirolisis didefiniskan sebagai proses degradasi termal dari padatan dalam kondisi tidak adanya oksigen, yang memungkinkan terjadinya beberapa jalur konversi thermokimia sehingga padatan tersebut menjadi gas (permanent gasses), cairan (pyrolitic liquid) dan padatan (char) (Di Blasi (2008). Sementara Swithenbank et.al (2005) mendefinisikan pirolisis sebagai degradasi termal atau deformasi limbah organik dalam kondisi tanpa oksigen dan dalam kondisi tekanan atmosfer atau vakum untuk menghasilkan char (carbonaceous char), minyak pirolisis, dan gas pada temperatur yang relatif rendah berkisar antara $400-800^{\circ} \mathrm{C}$. Penelitian pirolisi sampah kota pernah dilakukan oleh Ojolo dan Bamgboye (2005) dengan menggunakan sampel seberat $12 \mathrm{~kg}$ dengan temperatur pirolisis berkisar antara $400^{\circ} \mathrm{C}$ sampai dengan $650^{\circ} \mathrm{C}$ selama 4 jam, perbandingan produk yang didapatkan dari penelitian tersebut adalah 52,2\% tar, 25,2\% char dan 22,6\% gas. Sedangkan Yang et al. (2007) melakukan penelitian pirolisis lamban dari sampah kota terpisahkan dalam packed bed pyrolizer dengan berat sampel yang cukup banyak. Hasilnya diperoleh bahwa persentase char yang dihasilkan berkisar antara 21-34\%, tar 34-46\% dan gas 23-43\% pada kondisi temperatur pirolisis 350-700 ${ }^{\circ}$ C. Dari hasil pemodelan diketahui bahwa pada cardboard dan limbah tekstil, pemecahan tar tidak cukup untuk menimbulkan kenaikan pelepasan tar, hal ini diduga berhubungan dengan kandungan mineral yang dimiliki, hal tersbut diperkuat oleh Phan et al. (2008) melakukan penelitian mengenai karakterisasi produk yang dihasilkan dari proses slow pyrolisis sampah. Hasil penelitian menunjukkan bahwa untuk menghasilkan produk char dan tar yang optimum, maka temperature akhir proses slow pyrolisis seyogyanya di bawah $500^{\circ} \mathrm{C}$.

Sementara itu, penelitian karakteristik pembakaran char sampah kota dilakukan oleh Cheng et al. (2007), di mana proses pirolisis dilakukan dengan laju kenaikan temperatur $10^{\circ} \mathrm{C} /$ menit pada temperatur ruang $666^{\circ} \mathrm{C}$ sementara proses pembakaran dilakukan dengan memanaskan ruang pembakaran dengan laju kenaikan temperatur $10^{\circ} \mathrm{C} /$ menit hingga temperatur ruang bakar mencapai $1270^{\circ} \mathrm{C}$. Hasil penelitian menunjukkan bahwa selama proses pirolisis terjadi pengurangan berat sampel sebesar $60 \%$ dan dengan pelakuan penelitian tersebut diperkirakan energi yang mampu diperoleh sebesar $20.000 \mathrm{~kJ} / \mathrm{kg}$. Penelitian mengenai proses pirolisis dan pembakaran dari sampah juga dilakukan oleh Grammelis et al. (2009). Penelitian dilakukan dengan 5 sampel berbahan baku kayu, 6 sampel berbahan baku plastik dan 2 sampel RDF (Refused Derived Fuel). Pirolisis dilakukan pada kisaran temperatur $30^{\circ} \mathrm{C}$ sampai dengan $1000^{\circ} \mathrm{C}$ dengan laju kenaikan temperatur $20^{\circ} \mathrm{C} /$ menit, sementara proses pembakara dilakukan dengan kondisi termal yang sama. Hasil penelitian menunjukkan bahwa kinetika reaksi dekomposisi $R D F$ merupakan penjumlahan dari kinetika komponen penyusunnya dan juga $R D F$ dengan komponen plastik yang lebih tinggi menghasilkan char yang lebih rendah dengan reaktivitas yang rendah.

Pengolahan sampah kota menjadi $R D F$ dalam bentuk briket char telah diteliti oleh beberapa peneliti, dan tampak bahwa karakteristik pirolisis sampah kota dan pembakaran RDF sangat tergantung pada jenis sampel yang diteliti. Oleh karena itu, maka dalam artikel ini akan disajikan hasil penelitian mengenai pengolahan sampah kota. terseleksi menjadi $R D F$, dengan menggunakan sampel dari beberapa jenis sampah yang banyak dijumpai di Indonesia dan belum terolah secara maksimal.

\section{METODE}

\section{Bahan Penelitian}

Bahan dalam penelitian ini adalah sampah kota yang terdiri atas $70 \%$ (berat) sampah organik (yang terdiri dari sampah daun pisang dan sampah bambu) dan $30 \%$ (berat) sampah non organik (yang meliputi sampah kemasan dan sampah styrofoam). Pemilihan komposisi sampel penelitian didasarkan pada estimasi komposisi timbulan sampah yang ada saat ini.

\section{Peralatan Penelitian}

Peralatan yang digunakan dalam penelitian ini terdiri atas peralatan uji pirolisis yang sekaligus dapat berfungsi sebagai peralatan uji pembakaran. Peralatan uji pirolisis bertipe packed bed pyrolizer, yang diadaptasi dari penelitian Swithenbank et al. (2005), yang terdiri atas tungku pemanas yang dilengkapi dengan thermocontroller dengan pembacaan temperatur sampai dengan $1000^{\circ} \mathrm{C}$ dan reaktor untuk proses pirolisis dengan berdiameter 
$96 \mathrm{~mm}$ tinggi $500 \mathrm{~mm}$. Reaktor pirolisis tersebut dialiri gas nitrogen dari bawah reaktor. Gas nitrogen berasal dari tabung yang dilengkapi dengan pressure gauge dan rotameter guna mengatur laju aliran nitrogen. Sedangkan pada bagian atas tabung reaktor terdapat saluran untuk mengalirkan gas hasil pirolisis ke sistem pendingin. Untuk mengukur pengurangan massa sampel yang terjadi selama proses pirolisis, maka pada bagian tutup reaktor diberikan lubang berdiameter $5 \mathrm{~mm}$ untuk peletakan kawat yang menghubungkan sampel dengan timbangan digital. Untuk melakukan uji pembakaran, maka aliran gas nitrogen diganti menjadi aliran udara dari blower. Skematik peralatan penelitian tersaji dalam gambar 1.

\section{Cara Pengambilan Data}

Langkah pertama dalam penelitian ini adalah pengumpulan dan penyiapan bahan baku. Bahan baku yang dikumpulkan adalah sampah kota yang terdiri atas sampah kemasan, sampah yang berbahan baku biomass (daun pisang dan bambu), dan sampah styrofoam.

Sampah kota secara sederhana diartikan sebagai sampah organik maupun anorganik yang dibuang oleh masyarakat dari berbagai lokasi di kota tersebut. Sumber sampah umumnya berasal dari perumahan dan pasar. Permasalahan sampah merupakan hal yang krusial. Bahkan, sampah dapat dikatakan sebagai masalah kultural karena dampaknya terkena pada berbagai sisi kehidupan, terutama di kota-kota besar seperti Jakarta, Semarang, Bandung, Medan dan Surabaya. Menurut perkiraan, volume sampah yang dihasilkan perorang rata-rata sekitar $0,5 \mathrm{~kg} / \mathrm{kapita} /$ hari. Jadi, untuk kota besar seperti Jakarta yang penduduknya 10 juta orang sampah yang dihasilkan sekitar 5.000 ton/hari. Dengan jumlah yang tergolong besar tersebut, maka perlu adanya penanganan sampah yang khusus. Bila tidak cepat ditangani secara benar maka kota-kota di Indonesia akan tenggelam dalam timbunan sampah bersamaan dengan segala dampak negatif yang ditimbulkan. Sumber sampah yang terbanyak adalah dari pemukiman dan pasar tradisional. Sampah pasar khusus seperti sayurmayur, pasar buah, atau pasar ikan, jenisnya relatif seragam, sebagian besar (95\%) berupa sampah organik sehingga lebih mudah ditangani. Sampah yang berasal dari pemukiman umumnya sangat beragam, tetapi secara umum minimal $75 \%$ terdiri dari sampah organik dan sisanya anorganik. Meskipun hanya bahan organik yang biasa terurai oleh mikroba, tetapi setiap jenis bahan berbeda tingkat kemudahan dalam penguraiannya (degradibilitas).

Sampel kemudian dikeringkan sehingga memiliki kadar air maksimal 10\%. Dan dihaluskan hingga lolos ukuran 20 mesh. Setelah bahan baku terkumpul maka bahan baku yang berupa sampah organik dan sampah plastik tersebut diuji secara proximate dan

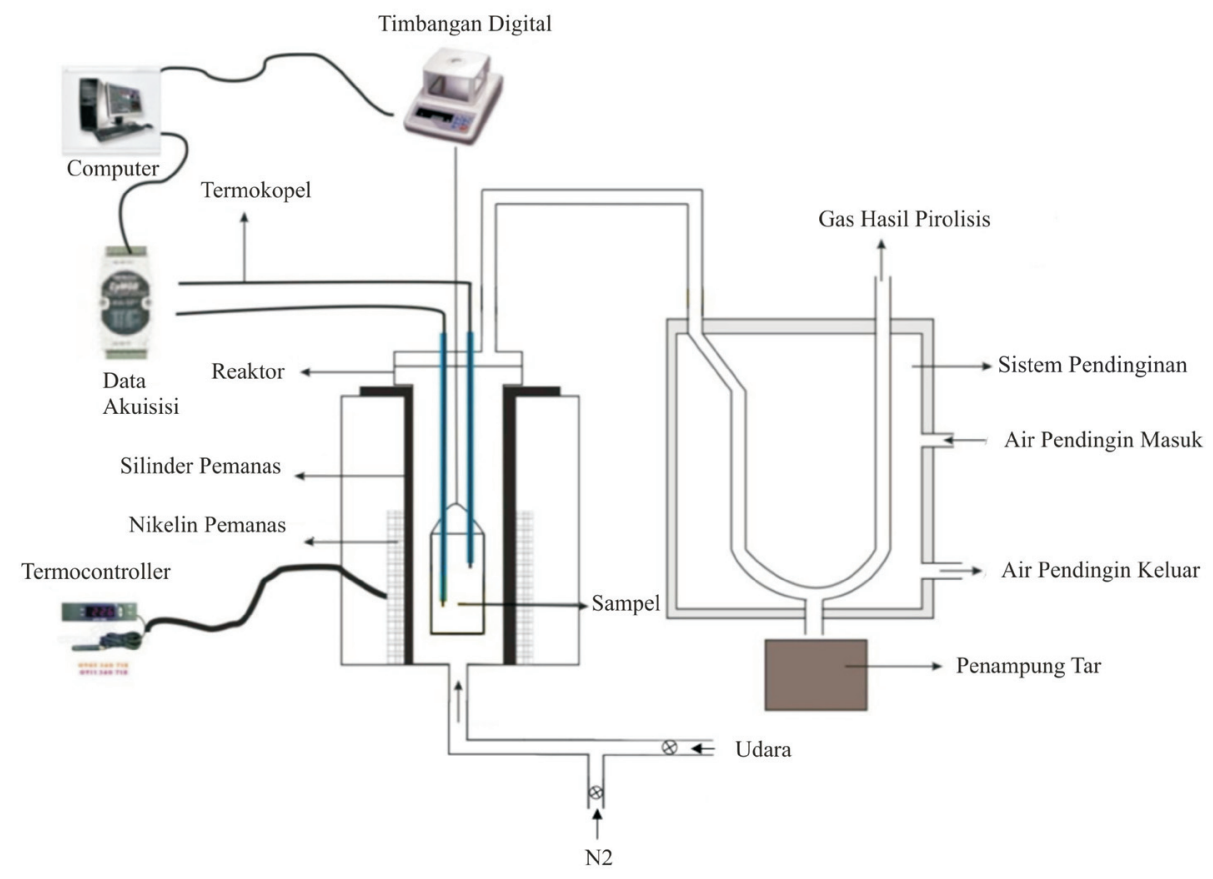

Gambar 1. Skematik Peralatan Penelitian 


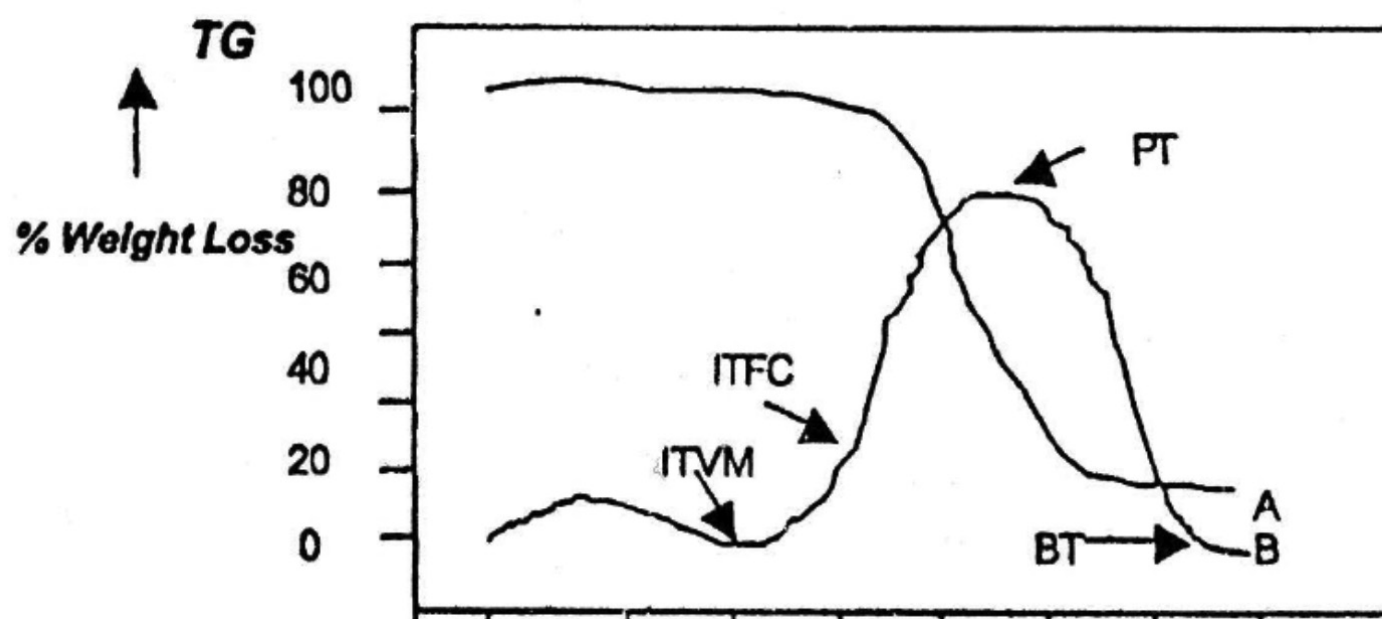

Gambar 2. Penentuan Zona Pembakaran Dengan Metoda Thermogravimetry

uji nilai kalor, pengujian meliputi nilai kalor (heating value) sesuai standar ASTM 2015, kadar air dengan standar pengujian ASTM D-3173, kadar abu sesuai dengan standar pengujian ASTM D-3174, kandungan volatile matter dengan standard ASTM D-3175 dan kadar fixed carbon sesuai dengan standar pengujian ASTM D-3172.

Tahap selanjutnya adalah proses pirolisis dan uji pembakaran dengan sampel 20 gram. Proses pirolisis yang dilakukan adalah proses slow pyrolisis dengan kenaikan temperatur pirolisis sebesar $10^{\circ} \mathrm{C} /$ menit dengan temperatur akhir proses slow pyrolisis sebesar $400^{\circ} \mathrm{C}$ serta lama proses karbonasi 30 menit. Setelah menjalani proses pirolisis, maka dilakukan uji proximate dan uji nilai kalor terhadap hasil proses slow pirolisis untuk mengetahu sifat-sifat char yang dihasilkan. Tahapan berikutnya adalah pembuatan briket char sampah kota dengan tekanan pengepresan $350 \mathrm{~kg} / \mathrm{cm}^{2}$, dengan berat briket 3 gram dan pengikat berupa tepung kanji (cassava starch) yang dihasilkan dari proses pirolisis sebesar 20\% dari berat sampel.

Uji karateristik pembakaran briket char sampah kota menggunakan metode thermogravimetri seperti terlihat dalam gambar 2 , untuk mengetahui karakteristik bahan bakar yang diuji (meliputi temperatur pembakaran di mana massa briket mulai berkurang (volatile matter initiation temperatur (ITVM)), temperatur ruang bakar di mana laju pengurangan massa meningkat selama proses awal pembakaran (fixed carbon initiation temperature (ITFC)), temperatur ruang bakar yang menghasilkan laju penurunan massa briket terbesar (peak temperature (PT)) dan temperatur ruang bakar di mana massa briket konstan pada akhir tahap pembakaran (burning temperature (BT)), metode ini dilakukan dengan cara menaikkan temperatur ruang bakar dari temperatur kamar secara bertahap dengan besar kenaikan konstan tiap waktu (direncanakan kenaikan temperatur $20^{\circ} \mathrm{C} /$ menit) sampai sampel bahan bakar terbakar habis.

\section{HASIL DAN PEMBAHASAN}

\section{Hasil Uji Proksimat Bahan Baku}

Dari uji proksimat bahan baku disajikan dalam tabel 1.

Uji proksimat dilakukan di PSPG PAU Universitas Gadjah Mada sesuai dengan standar pengujian yang mengacu pada ASTM D1762-84. Dari uji proksimat terlihat bahwa kadar fixed carbon pada kemasan memiliki harga paling rendah. Data-data yang didapatkan mendekati data uji proksimat yang diperoleh dari penelitian Grammelis (2009).

Tabel 1. Hasil Uji Proksimat Bahan Baku

\begin{tabular}{|c|c|c|c|c|c|}
\hline Bahan & Kadar abu (\%) & Kadar air (\%) & $\begin{array}{c}\text { Kadar Volatile } \\
\text { Matter }(\%)\end{array}$ & $\begin{array}{c}\text { Kadar Karbon } \\
\text { Tetap }(\%)\end{array}$ & $\begin{array}{c}\text { Nilai Kalor } \\
\text { (kal/gram) }\end{array}$ \\
\hline bambu & 8.005 & 7.315 & 80.376 & 4.304 & 4001.563 \\
\hline daun & 13.56 & 10.155 & 73.008 & 3.277 & 4189.169 \\
\hline kemasan & 1.81 & 0.955 & 95.545 & 1.69 & 8326.184 \\
\hline styrofoam & 2.54 & 0.55 & 86.281 & 10.629 & 9414.385 \\
\hline
\end{tabular}


Karakteristik Pembakaran

Briket $70 \%$ Organik - $30 \%$ Anorganik
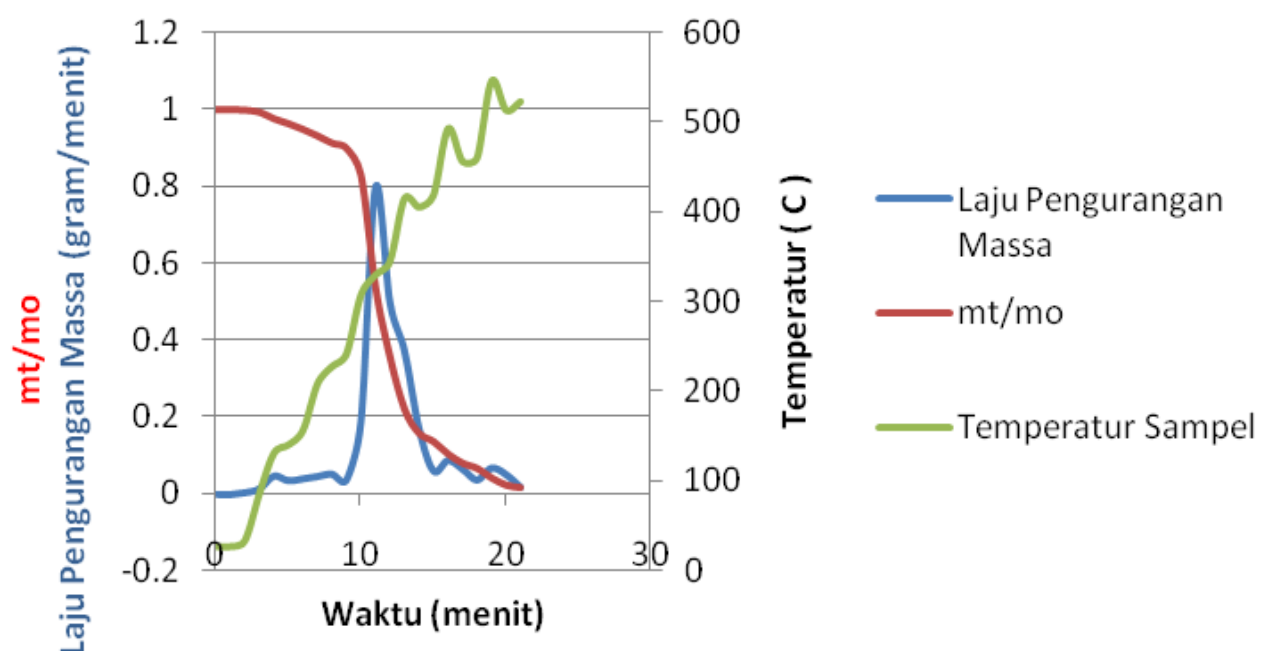

Gambar 3. Karakteristik Pembakaran Briket Sampah 70\% Organik - 30\% Non Organik

Dari hasil uji proksimat, tampak bahwa komponen non organik memiliki nilai kalor yang tinggi, namun disisi lain, disadari melakukan pembakaran secara langsung terhadap komponen-komponen tersebut akan membawa dampak buruk bagi lingkungan.

\section{Karakteristik Pembakaran Briket Sampah Kota Tanpa Pirolisis}

Karakteristik pembakaran briket sampah kota tanpa pirolisis dapat dilihat pada gambar 3. Secara teoritis, proses pembakaran bahan bakar padat dapat dibagi menjadi tiga tahapan, yaitu tahap pengeringan, tahap devolatilisasi, tahap pembakaran arang, dan akan tersisa abu. (Ragland dan Borman, 1998)

Berdasarkan gambar 3, terlihat bahwa proses pengeringan dimulai pada temperatur sekitar $52^{\circ} \mathrm{C}$. Hal ini terlihat dari penurunan massa yang landai. Proses pengeringan berlangsung sampai temperatur $268^{\circ} \mathrm{C}$ menyisakan massa sebesar $90 \%$. Berakhirnya proses pengeringan diikuti dengan mulainya proses devolatilisasi yang ditandai dengan penurunan massa yang sangat tajam. Proses devolatilisasi dimulai pada temperatur $268^{\circ} \mathrm{C}$ dan berakhir pada temperatur $428^{\circ} \mathrm{C}$. Pada proses devolaitisasi ini massa berkurang hingga menyisakan $20 \%$ dari massa awal. Setelah proses devolatilisasi selesai maka akan diikuti proses pembakaran char. Pada pembakaran char ini massa akan berkurang sampai hanya tertinggal 0,44\%.Temperatur akhir pembakaran adalah $579^{\circ} \mathrm{C}$ di mana pada temperatur ini char hampir terbakar habis dan menyisakan abu. Berdasarkan gambar 3, ITVM terjadi pada temperatur $241,8^{\circ} \mathrm{C}$, ITFC pada $307,8^{\circ} \mathrm{C}$, PT pada temperatur $330,1^{\circ} \mathrm{C}$ dan $\mathrm{BT}$ terjadi pada temperatur $491^{\circ} \mathrm{C}$

\section{Penentuan Energy Recovery Proses Pirolisis}

Menentukan, komposisi dan teknologi slow pyrolisis yang tepat guna menghasilkan char yang optimum maka perlu mempertimbangkan banyak hal, disebabkan proses slow pyrolisis dapat menghasilkan char dengan nilai kalor yang relatif tinggi namun pengurangan massa akibat proses pirolisis juga cukup besar, sehingga perlu optimasi di antara keduanya, dan juga perlu dipertimbangkan pula pasokan energi yang diperlukan untuk menghasilkan char tersebut. Oleh karena itu dalam menentukan teknologi proses yang tepat digunakan satu besaran yaitu energy yield, yaitu banyaknya energi yang dapat diselamatkan (energy recovery) selama proses pirolisis (Swithenbank (2005), dengan rumusan perbandingan antara nilai kalor char yang dihasilkan dan nilai kalor bahan baku dikalikan dengan massa char yang tersisa setelah proses pirolisis. Hasil penelitian, didapatkan bahwa massa char yang tersisa setelah proses pirolisis adalah sebesar 29,49\%, sementara nilai kalor char yang dihasilkan sebesar $5.527,846 \mathrm{kal} / \mathrm{gram}$ dan nilai kalor briket sampah kota adalah sebesar 5460,68 sehingga energy yield proses pirolisis yang diteliti adalah sebesar $29,13 \%$.

\section{Karakteristik Pembakaran Briket Char}

Karakteristik pembakaran briket char hasil pirolisis campuran dengan komposisi organikanorganik 70-30 ditampilakan pada gambar 4 . Dari gambar tersebut, tampak bahwa pembagian zona pengeringan dan devolatilisasi tidak begitu jelas terlihat, hal inilah yang membedakan dengan pembakaran briket tanpa perlakuan pirolisis. Dari gambar tersebut, tampak bahwa ITVM terjadi pada temperatur $197,5^{\circ} \mathrm{C}$, ITFC pada temperatur $298,8^{\circ} \mathrm{C}$, 


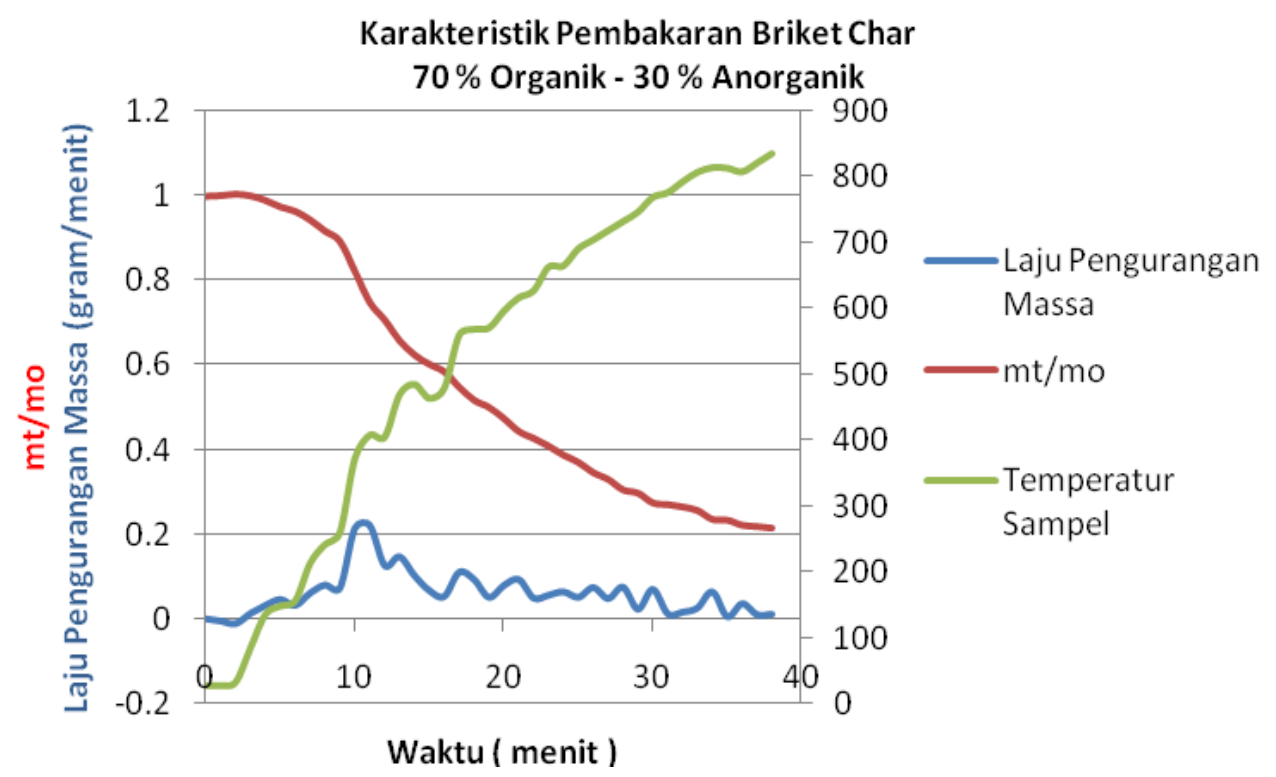

Gambar 4. Karakteristik Pembakaran Briket Char Sampah 70\% Organik - 30\% Non Organik

sementara PT terjadi pada temperatur $429,5^{\circ} \mathrm{C}$. Data yang didapatkan, terlihat bahwa proses pembakaran briket char terjadi pada ITVM dan ITFC yang lebih rendah bila dibandingkan dengan briket tanpa pirolisis, hal ini menunjukkan bahwa briket char lebih mudah dibakar bila dibandingkan dengan briket tanpa perlakukan pirolisis. Hal lain yang menarik untuk dicermati adalah briket char memiliki PT yang terjadi pada temperatur yang lebih tinggi dibandingkan dengan briket tanpa perlakuan pirolisis, hal ini menunjukkan bahwa briket char memiliki kecepatan pengurangan massa yang lebih rendah daripada briket tanpa pirolisis.

\section{SIMPULAN}

Hasil pengambilan dan pengolahan data dapat disimpulkan bahwa proses pirolisis terhadap sampel sampah kota dengan komposisi $70 \%$ organik - 30\% non organik akan menghasilkan massa char yang tersisa setelah proses pirolisis sebesar $29,49 \%$, dengan nilai kalor char yang dihasilkan sebesar 5.527,846 $\mathrm{kal} / \mathrm{gram}$, sehingga energy yield proses pirolisis yang diteliti adalah sebesar $29,13 \%$. Sementara itu, proses pembakaran briket char sampel yang diteliti terjadi pada ITVM dan ITFC yang lebih rendah daripada briket non pirolisis, namun penurunan massa maksimum terjadi pada temperatur yang lebih besar, sehingga dapat disimpulkan briket char yang diteliti lebih mudah terbakar namun lebih awet dalam pembakaran.

\section{UCAPAN TERIMA KASIH}

Penelitian ini merupakan sebagian dari hasil penelitian Hibah Penetian Disertasi Doktor Tahun Anggaran 2010 yang didanai oleh DP2M Ditjen DIKTI Kementerian Pendidikan Nasional Republik Indonesia. Dalam kesempatan ini, tim peneliti ingin mengucapkan terima kasih kepada semua asisten penelitian yang terlibat dalam kegiatan penelitian ini.

\section{DAFTAR PUSTAKA}

Borman, G.L., Ragland, K.W. 1998. Combustion Engineering, International Editions. WCB/McGrawHill, Singapore.

Cheng, Z., Chen, H., Zhang, Y., Hack, P., Pan, W.P., 2007. An Application of Thermal Analysis to Household Waste. Journal of ASTM International Vol, 4 No. 1., Paper ID: JAI100523.

Di Blasi, C. 2008. Modeling Chemical and Physical Processes of Wood and Biomass Pyrolisis. Progress in Energy and Combustion Science 34, pp. 47-99.

Grammelis, P., Basinas, P., Malliopoulou, A., Sakellaropoulos, G. 2009. Pyrolisis Kinetics and Combustion Characteristics of Waste Recovered Fuels. Fuel 88, pp. 195-205.

Ojolo, S.J., Bamgboye, A.I. 2005. Thermochemical conversion of Municipal Solid Waste to Produce Fuel and Reduce Waste. The CIGR Ejournal, Vol. VII, Manuscript EE 05006.

Phan, A.N., Ryu, C., Sharifi, V.N., Swithenbank, J. 2008. Characterisation of Slow Pyrolisis Products from Segregated Wastes for Energy Production. J.Anal. Appl.Pyrolisis 81, pp. 65-71. 
Yang, Y.B., Phan, A.N., Ryu, C., Sharifi, V.N., Swithenbank, J. 2007. Mathematical Modelling of Slow Pyrolisis of Segregated Solid Wastes in a Packed-Bed Pyrolyser. Fuel 86, 169-180.

Swithenbank, J., Sharifi, V.N., Ryu, C. 2005. Waste Pyrolisis and Generation of Storable Fuel, SUWIC
Department of Chemical and Process Engineering. The University of Sheffield.

Turn, Stephen R. 1996. An Introduction to Combustion. McGraw-Hill.

Yang, Y.B., Phan, A.N., Ryu, C.,Sharifi, V.,Swithenbank, J. 2007. Mathematical Modelling of Slow Pyrolisis of Segregated Solid Waste in A Packed-Bed Pyroliser, Fuel 86, pp. 169-180. 